\title{
Perbaikan Postur Kerja Pada Operator Stasiun Two For One Atas Menggunakan Metode REBA
}

\author{
Improvement of Work Posture on the Operator of Top Two For One Station \\ Using REBA Method
}

\author{
Evita, Elty Sarvia \\ Program Studi Teknik Industri, Universitas Kristen Maranatha Bandung \\ Email: evitatjen19@yahoo.com, elty.sarvia@eng.maranatha.edu
}

\begin{abstract}
Abstrak
Industri tekstil saat ini menjadi salah satu industri yang berkembang pesat di Indonesia. Keterlibatan manusia dalam mengoperasikan sistem dan membawa WIP juga tinggi sehingga menunjukkan adanya gejala Musculoskeletal Disorders (MSDs) yang dialami oleh operator. Tujuan dari penelitian ini adalah menganalisis aktivitas yang dilakukan oleh operator, menganalisis resiko MSDs pada operator dan merancang usulan alat bantu yang dapat mengurangi resiko MSDs. Sakit yang dirasakan operator diukur dengan menggunakan Kuesioner Nordic Body Map yang menunjukkan operator mengalami sakit pada area tubuh leher, lengan, punggung, dan lutut.. Untuk mengukur resiko MSDs pada operator, maka digunakan metode REBA yang secara objektif dapat menyatakan resiko dari aktivitas yang dilakukan oleh operator. Hasil yang didapatkan dari pengolahan data REBA menunjukkan adanya resiko menengah dari pekerjaan yang dilakukan oleh operator, sehingga dirancang alat bantu berupa pijakan kaki yang dapat menurunkan resiko MSDs menjadi resiko rendah. Kata kunci: Kuesioner Nordic Body Map, MSDs, REBA
\end{abstract}

\begin{abstract}
The textile industry is one of the fastest growing industries in Indonesia. Human involvement in operating the system and carrying WIP is also high and indicating a symptoms of MSDs experienced by the operator. The purpose of this study is to analyze activities that performed by the operator, to analyze the risk of MSDs in the operators and to design the tools that can reduce the risk of MSDs. The operator's perceived pain was measured using the Nordic Body Map Questionnaire and show that operators experienced pain in the neck, arms, back and knee area. To measure the risk of MSDs in the operator, REBA method can objectively show the risks of the activities performed by the operator. The results obtained from REBA indicate the medium risk of work performed by the operator, so a tool was designed to reduce the risk of MSDs into low risk.
\end{abstract}

Keywords: Nordic Body Map Questionnaire, MSDs, REBA

\section{Pendahuluan}

Kelelahan dini pada pekerja dapat menimbulkan penyakit akibat kerja dan kecelakaan kerja bagi pekerja. Oleh sebab itu, untuk mengantisipasi hal tersebut maka setiap perusahaan wajib memperhatikan tentang kesehatan dan keselamatan bagi pekerjaannya dengan cara penyesuaian antara pekerja dengan metode kerja, mesin, proses kerja dan lingkungan kerja. Musculoskeletal disorders (MSD) adalah masalah ergonomi yang sering dijumpai ditempat kerja, khususnya yang berhubungan dengan kekuatan dan ketahanan manusia dalam melakukan pekerjaannya. Masalah tersebut lazim dialami oleh para pekerja yang melakukan gerakan yang sama dan berulang secara terus menerus. Rasa sakit (capek atau cepat lelah ini karena prosedur kerja dan perancangan fasilitas kerja yang kurang ergonomis, kondisi ini akan memberikan dampak pada hasil produktivitas kerja yang tidak optimal selain berpotensi cidera pada bagian tubuh tertentu akibat aktifitas kerja yang tidak seimbangan dengan keterbatasan manusia (susihono, 2009).

Dari hasil wawancara yang dilakukan terhadap operator stasiun Two For One Atas, operator mengeluh mengalami sakit dan kekakuan pada punggung, leher, dan lengan karena bekerja dengan postur kerja yang tidak baik di mana operator harus melakukan pemindahan WIP ke mesin Two For One atas dan setup pada mesin Two For One atas secara berulang-ulang dan posisi mesin yang 
terlalu tinggi. Berdasarkan penjabaran latar belakang masalah di atas maka dapat diketahui faktorfaktor yang menimbulkan masalah. Faktor-faktor tersebut adalah seperti postur tubuh yang tidak baik sehingga mengakibatkan sakit pada bagian tubuh operator, belum adanya alat bantu kerja yang ergonomis bagi operator untuk mengurangi rasa sakit, dan tempat peletakan dan setup WIP ke stasiun kerja Two For One atas yang terlalu tinggi dan pengulangan yang sangat banyak. Penelitian sebelumnya dilakukan terhadap operator stasiun Two for One Bawah, dapat disimpulkan bahwa pada aktivitas pengerjaan pada rak bawah dan TFO bawah memiliki resiko tinggi, sehingga diusulkan Kneeling chair yang membantu operator dalam pekerjaannya (Evita dan Elty Sarvia, 2017). Sedangkan penelitian ini khususnya pada proses pemindahan WIP \& setup stasiun kerja Two For One atas dan hanya untuk postur kerja operator saat pemindahan WIP \&setup pada proses Two For One atas. Adapun Pengamatan yang dilakukan dalam penganalisis postur kerja dengan menggunakan metode REBA terdiri atas 4 skenario, yaitu:

- Posisi mengambil gulungan benang dari rak benang tingkat tengah (Skenario $1 \mathrm{~b}$ )

- Posisi mengambil gulungan benang dari rak benang tingkat tertinggi (Skenario 1c)

- Posisi mengambil gulungan benang dari mesin Two For One bagian atas (Skenario 2b)

- Posisi.meletakkan WIP ke mesin Two For One bagian atas(Skenario 3b)

- $\quad$ Posisi mengambil benang dari gulungan bagian TFO atas (Skenario 4c)

- $\quad$ Posisi melilitkan benang pada penggulung untuk di twist pada TFO bagian atas (Skenario 4d)

Adapun tujuan dari penelitian ini adalah untuk mengetahui dan menganalisis keluhan operator terkait dengan aktivitas pemindahan WIP dan setup Operator TFO atas berdasarkan hasil dari kuesioner Nordic Body Map dan metode REBA (Rapid Entire Body Assesment), merancang usulan alat bantu untuk mengurangi tingkat resiko cedera yang terjadi pada operator di stasiun Two For One atas.

\section{Tinjauan Pustaka}

\subsection{Ergonomi}

Istilah "ergonomi" berasal dari bahasa latin yaiu ergon (kerja) dan nomos (hukum alam) dan dapat didefinisikan sebagai studi tentang aspek-aspek manusia dalam lingkungan yang ditinjau secara anatomi, fisiologi, psikologi, engineering, manajemen dan desain atau perancangan (Nurmianto, 2004).

\subsection{Biomekanika Kerja}

Biomekanika adalah ilmu yang meenggunakan hukum-hukum fisika dan mekanika teknik untuk mendeskripsikan gerakan pada bagian tubuh (kinematik) dan memahami efek gaya dan momen yang terjadi pada tubuh (kinetik) (Chaffin, 2006). Biomekanika juga merupakan keilmuaan yang mengombinasikan hukum-hukum fisika dan konsep-konsep teknik dengan pengetahuan dari keilmuan biologi dan perilaku manusia (Chaffin, 2006).

\subsection{Rapid Entire Body Assessment (REBA)}

Rapid Entire Body Assessment (REBA) merupakan sebuah metode yang digunakan untuk menilai tingkat risiko dari sebuah postur kerja. REBA dikembangkan oleh Sue dan Hignett dan dikenalkan pertama kali kepada publik pada tahun 2000. Pengembangan metode ini didasarkan pada beberapa metode assessment ergonomika sebelumnya seperti NIOSH Lifting Equation, Rating of Perceived Exertion, OWAS, Body Part Discomfort Survey dan Rapid Upper Limb Assessment (Sue dan Hignett, 2000).

\subsection{Antropometri}

Antropometri berarti pengukuran tubuh manusia. Hal ini berasal dari bahasa Yunani anthropos yang berarti manusia dan metro yang berarti ukuran. Antropometri menurut Stevenson (1989) dan Nurmianto (1991) adalah satu kumpulan data numerik yang berhubungan dengan karaktersitik fisik tubuh manusia ukuran, bentuk dan kekuatan serta penerapan dari data tersebut untuk penanganan masalah desain. 


\section{Pembahasan}

Foto postur tubuh operator akan diambil hanya dalam 1 sisi yaitu sisi kiri dikarenakan posisi tubuh operator pada bagian kiri maupun kanan berada dalam range yang sama. Untuk foto postur tubuh operator seperti pada gambar dibawah ini terdiri dari beberapa skenario, yaitu: posisi mengambil gulungan benang dari rak benang tingkat tengah (Skenario 1b), posisi mengambil gulungan benang dari rak benang tingkat tertinggi (Skenario 1c), posisi mengambil gulungan benang dari mesin Two For One bagian atas(Skenario 2b), posisi.meletakkan WIP ke mesin Two For One bagian atas(Skenario 3b), posisi mengambil benang dari gulungan bagian TFO atas (Skenario 4c), dan posisi melilitkan benang pada penggulung untuk di twist pada TFO bagian atas (Skenario 4d)

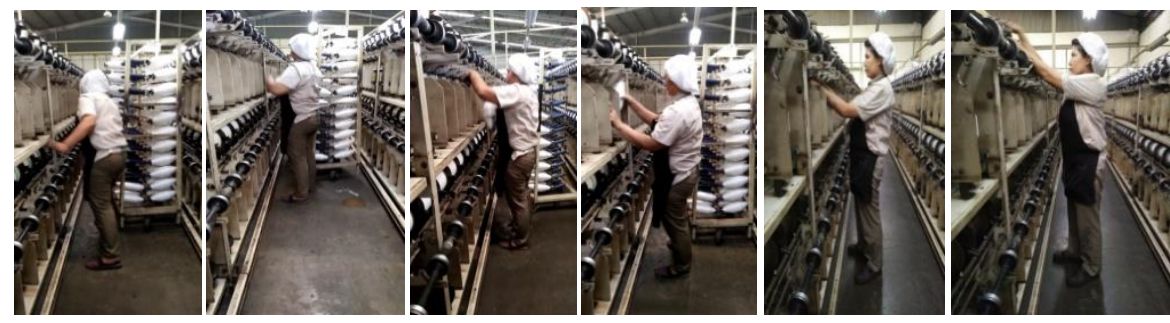

Gambar 1. Foto Postur Tubuh Operator

\subsection{Pengolahan Kuesioner Nordic Body Map}

Hasil kuesioner Nordic Body Map menunjukkan adanya rasa sakit pada bagian leher, punggung, lengan, dan lutut terhadap aktivitas yang dilakukan oleh operator tersebut. Hal ini disebabkan karena adanya pengulangan pekerjaan yang terlalu sering dan juga sudut tubuh yang terbentuk pada saat melakukan pekerjaan kurang baik dikarenakan letak dari mesin TFO Atas terlalu tinggi.

\subsection{Identifikasi Sudut Tubuh Operator}

Sudut tubuh operator digambarkan dengan menggunakan aplikasi ergofellow yang nantinya menjadi inputan dalam metode REBA. Berikut merupakan identifikasi sudut tubuh operator dari neck, trunk, leg, upper arm, lower arm, dan wrist.

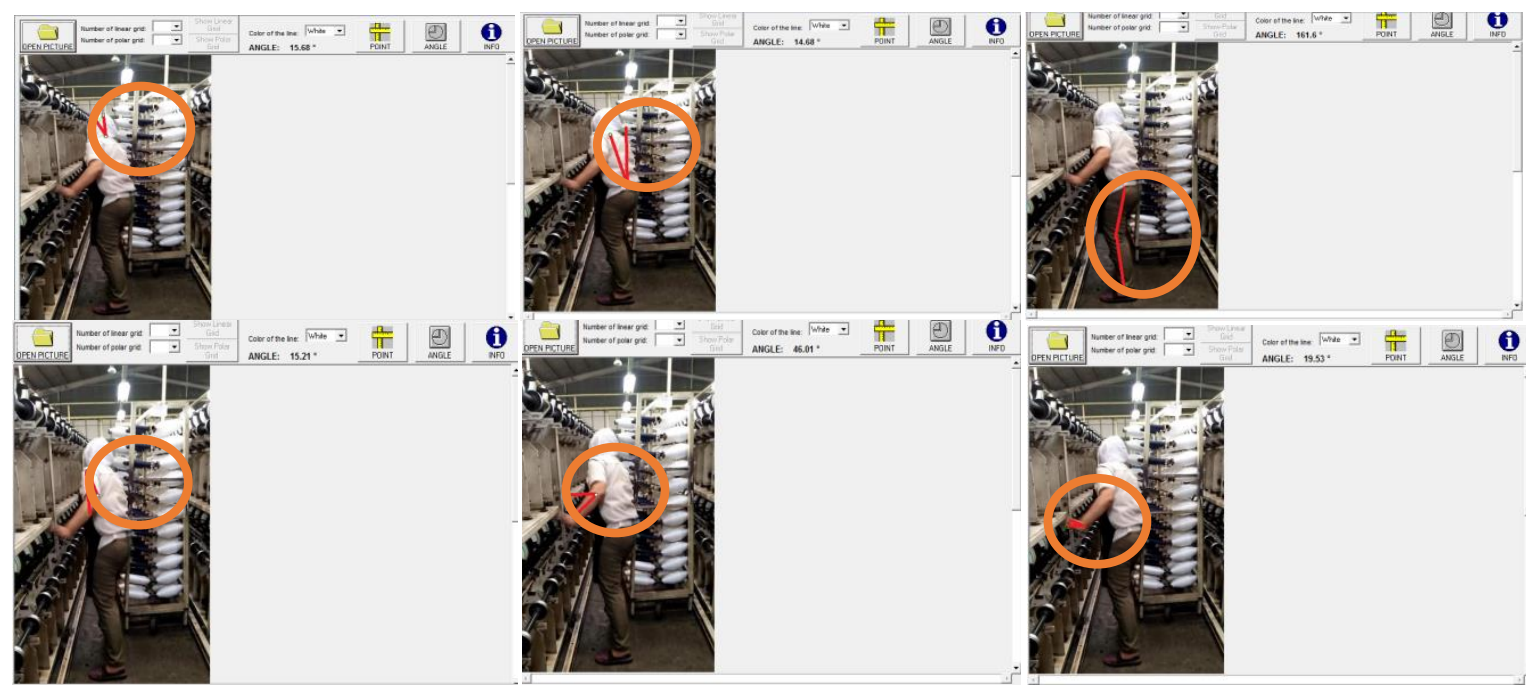

Gambar 2. Identifikasi Sudut Tubuh Operator Pada Posisi Mengambil Gulungan Benang dari Rak Benang Tingkat Tengah (Skenario 1b) 
PERBAIKAN POSTUR KERJA (Evita, dkk.)

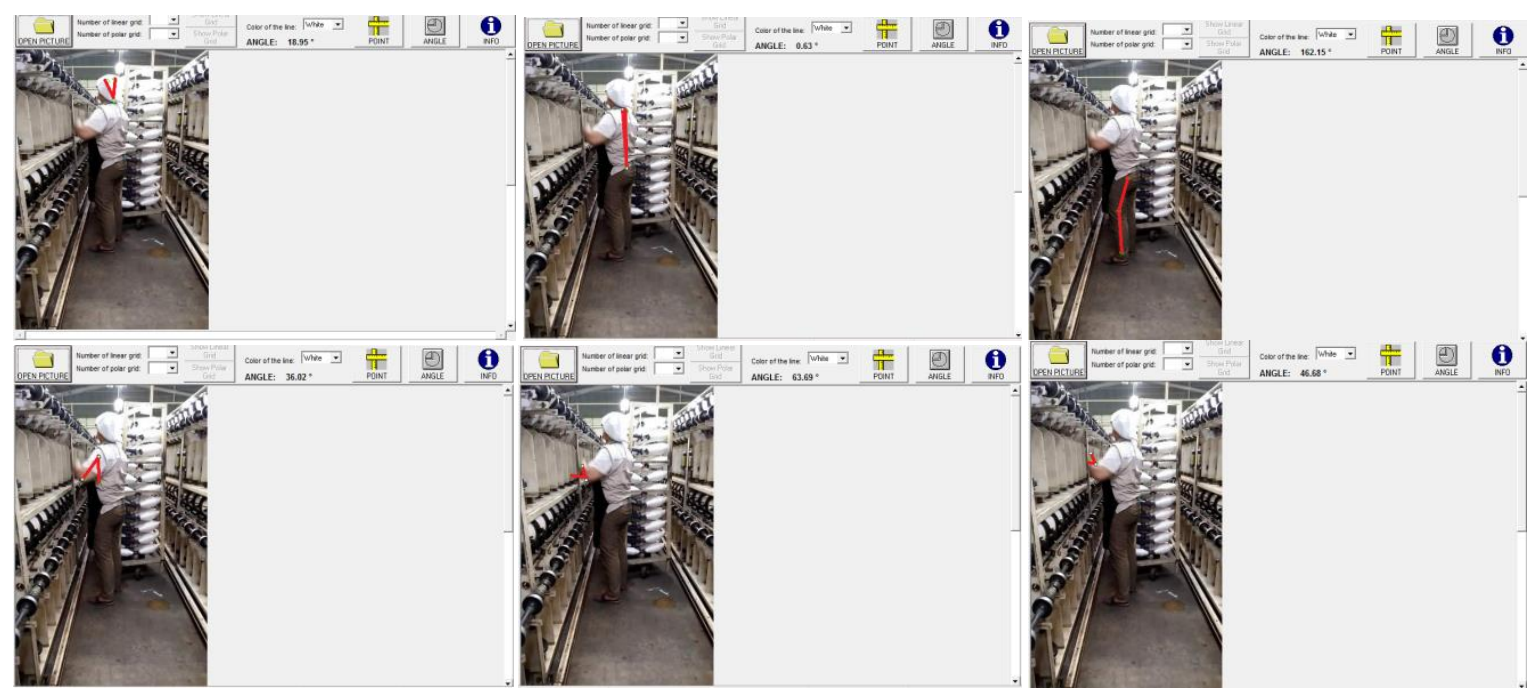

Gambar 3. Identifikasi Sudut Tubuh Operator Pada Posisi Mengambil Gulungan Benang dari Rak Benang Tingkat Atas (Skenario 1c)

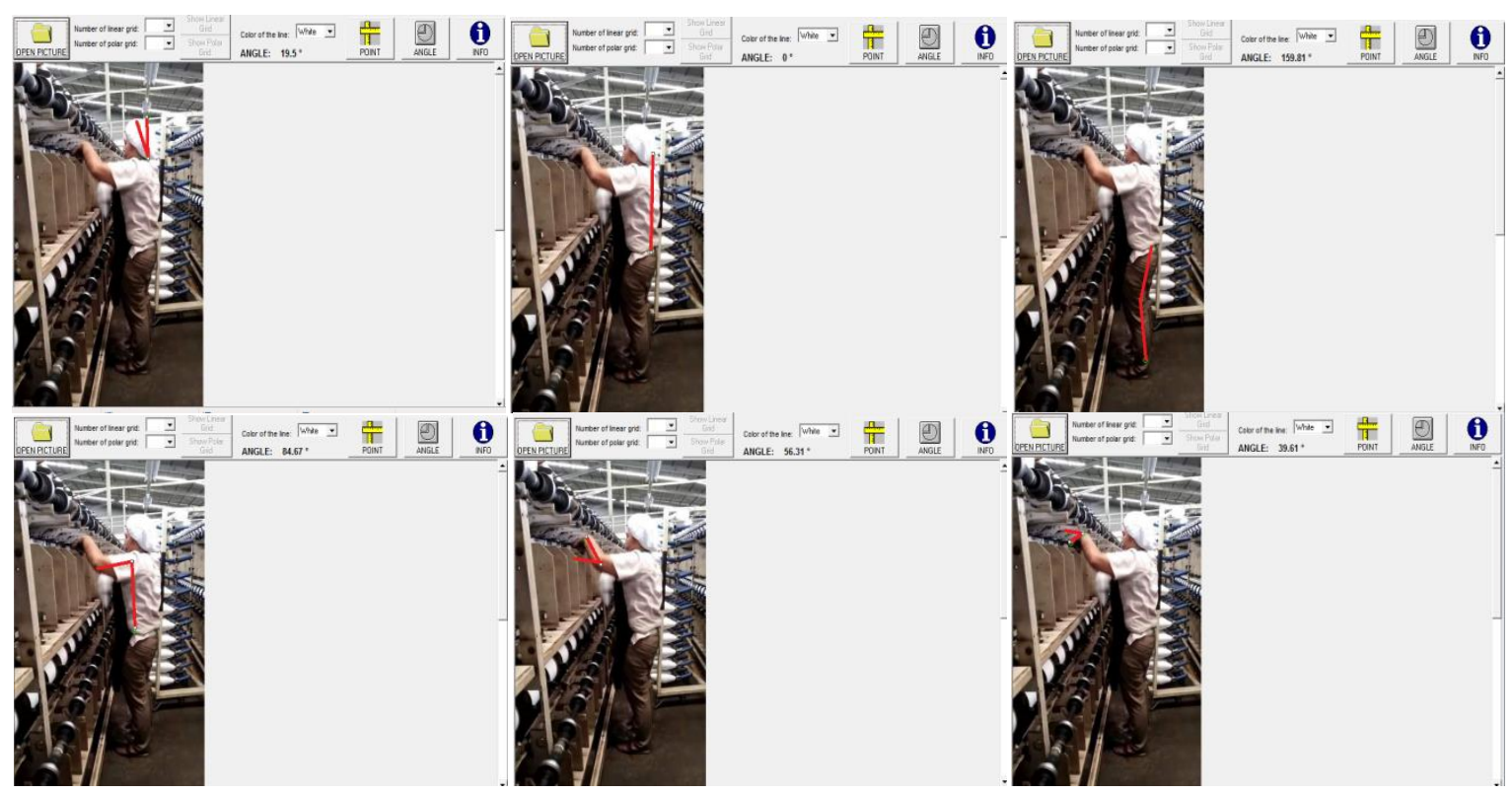

Gambar 4. Identifikasi Sudut Tubuh Operator Pada Posisi Mengambil Gulungan Benang dari Mesin Two For One Atas (Skenario 2b) 


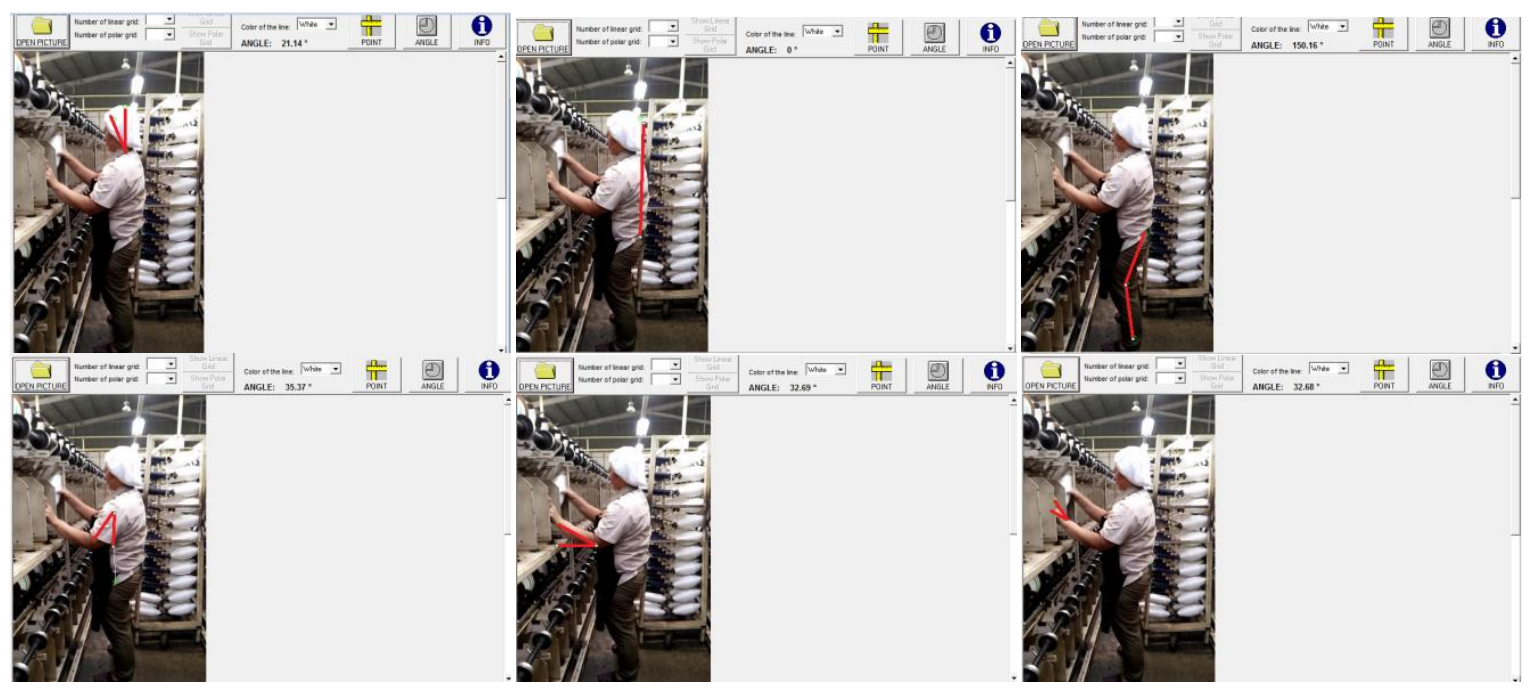

Gambar 5. Identifikasi Sudut Tubuh Operator Pada Posisi Meletakkan WIP Ke Mesin Two For One Atas (Skenario 3b)

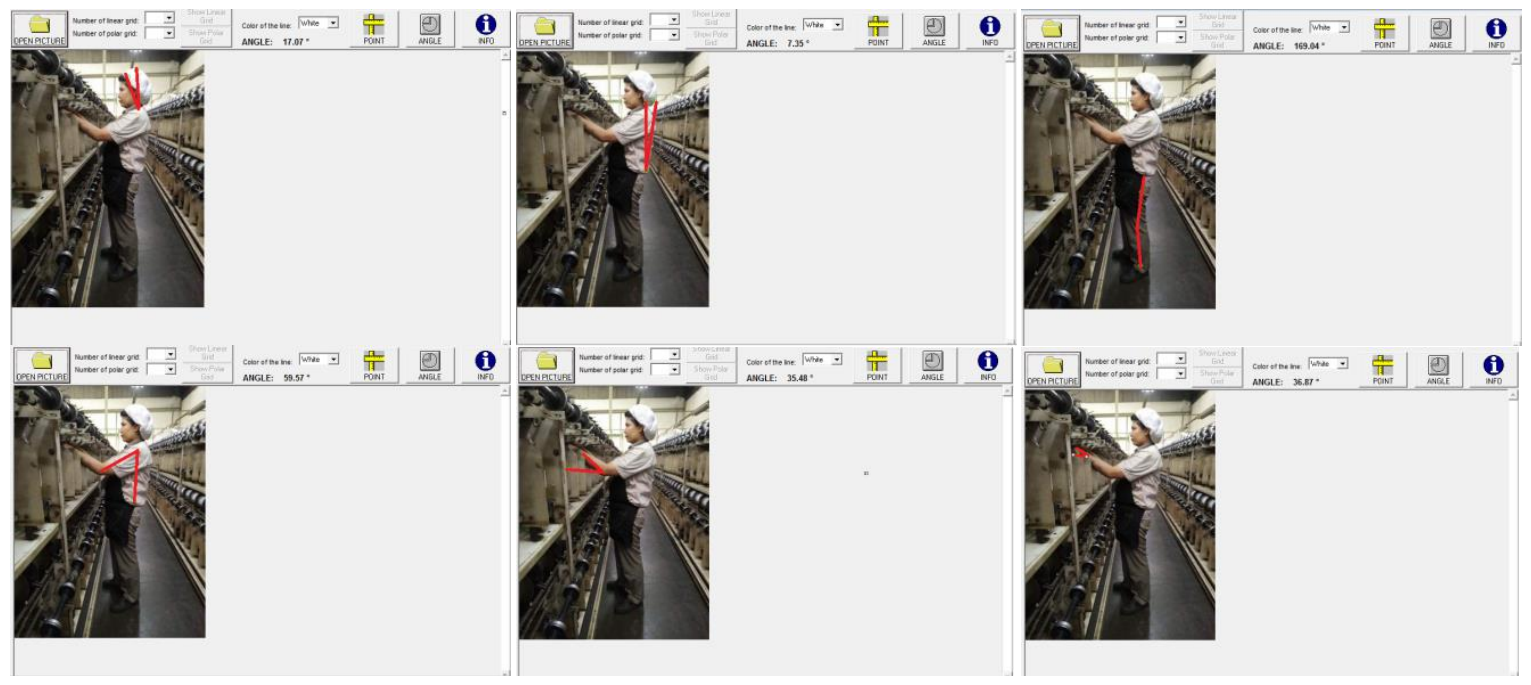

Gambar 6. Identifikasi Sudut Tubuh Operator Pada Posisi Melakukan Setup Mengambil Benang Dari Gulungan TFO Atas (Skenario 4c)

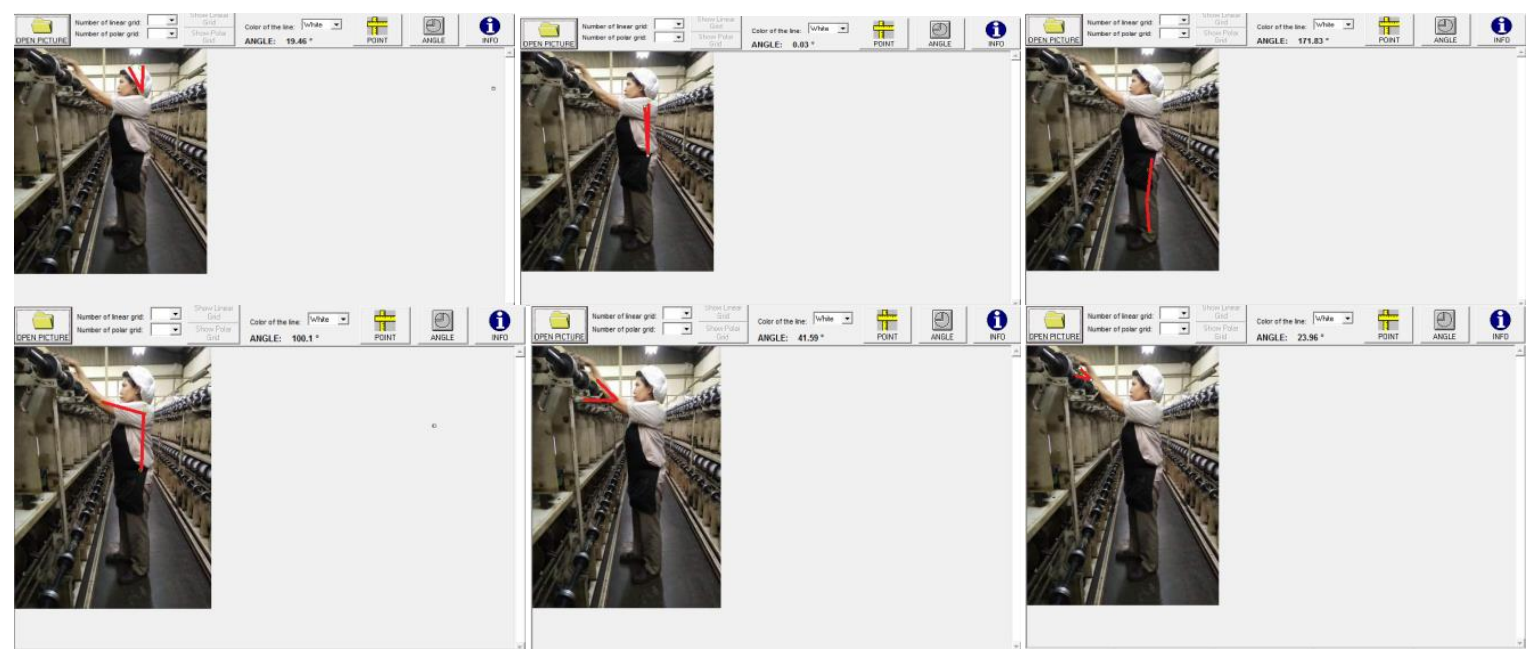

Gambar 7. Identifikasi Sudut Tubuh Pada Posisi Melakukan Setup Melilitkan Benang pada Penggulung untuk Di Twist pada TFO bagian atas (Skenario 4d) 
PERBAIKAN POSTUR KERJA (Evita, dkk.)

Berikut merupakan rangkuman identifikasi sudut tubuh operator untuk posisi diatas :

Tabel 1. Rangkuman Identifikasi Sudut Tubuh untuk TFO Atas

\begin{tabular}{|c|c|c|c|c|c|c|}
\hline Bagian Tubuh & Sudut Skenario 1b & Sudut Skenario 1c & Sudut Skenario 2b & Sudut Skenario 3b & Sudut Skenario 4c & Sudut Skenario 4d \\
\hline Neck & 15.68 & 18.95 & 19.5 & 21.14 & 17.07 & 19.46 \\
\hline Trunk & 14.68 & 0.63 & 0 & 0 & 7.35 & 0.03 \\
\hline Leg & 161.6 & 162.15 & 159.81 & 150.16 & 169.04 & 171.83 \\
\hline Upper Arm & 15.21 & 36.02 & 84.67 & 35.37 & 59.57 & 100.1 \\
\hline Lower Arm & 46.01 & 63.69 & 56.31 & 32.69 & 35.48 & 41.59 \\
\hline Wrist & 19.53 & 46.68 & 39.61 & 32.68 & 36.87 & 23.96 \\
\hline
\end{tabular}

\subsection{Pengolahan Metode REBA}

Penilaian resiko cedera pada tubuh operator akan dilakukan dengan tools REBA dari posisi posisi mengambil gulungan benang dari rak benang tingkat tengah (Skenario 1b), posisi mengambil gulungan benang dari rak benang tingkat tertinggi (Skenario 1c), posisi mengambil gulungan benang dari mesin Two For One bagian atas(Skenario 2b), posisi.meletakkan WIP ke mesin Two For One bagian atas (Skenario 3b), posisi mengambil benang dari gulungan bagian TFO atas (Skenario 4c), dan posisi melilitkan benang pada penggulung untuk di twist pada TFO bagian atas (Skenario 4d). Berikut merupakan hasil penilaian neck, trunk, leg, load, upper arm, lower arm, wrist, coupling, dan activity:

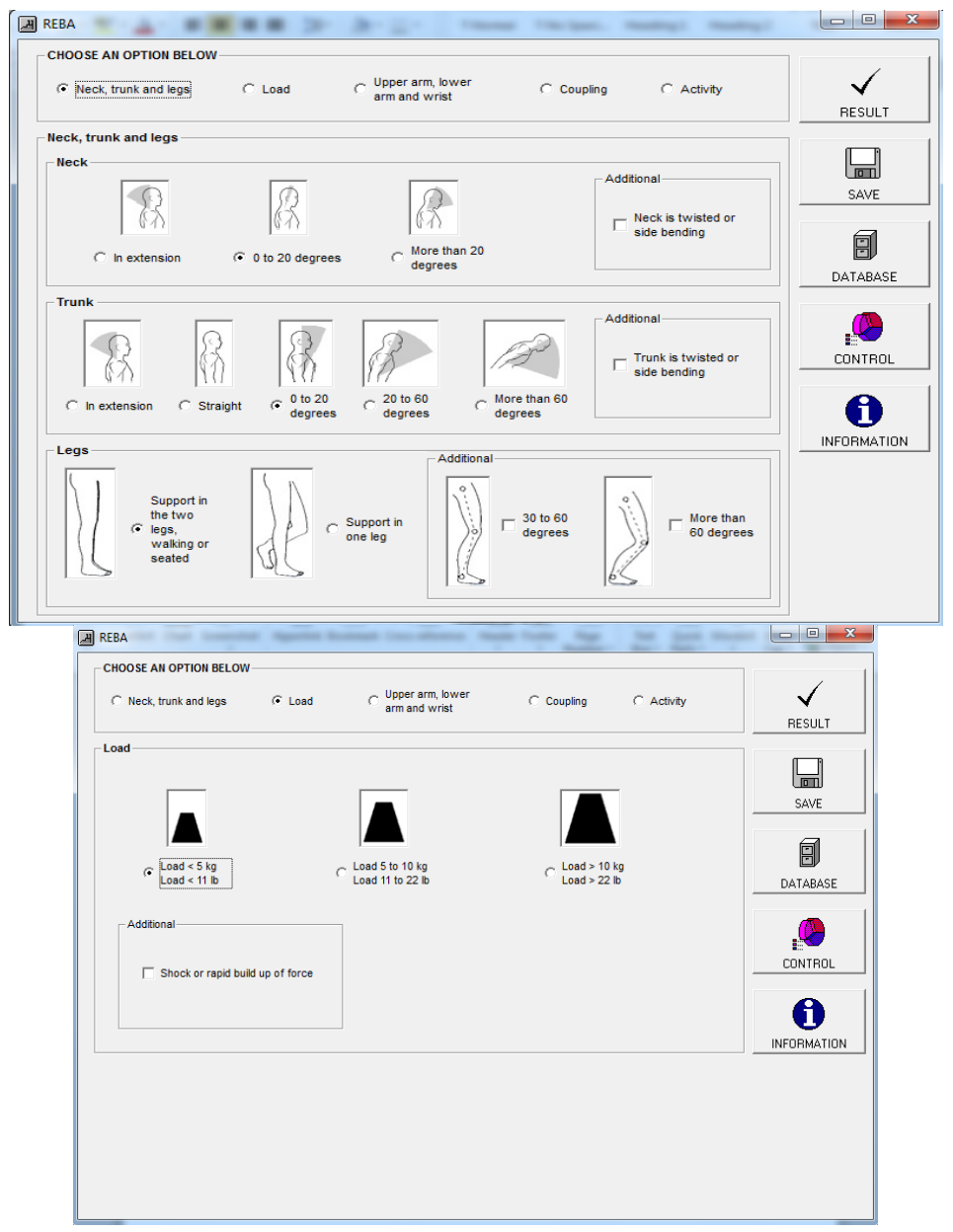

Gambar 8. Pengolahan Data REBA Posisi Mengambil Gulungan Benang dari Rak Benang Tingkat Tengah (Skenario 1b) 
JOURNAL OF INTEGRATED SYSTEM VOL 2. NO. 1, JUNI 2019: 37-50

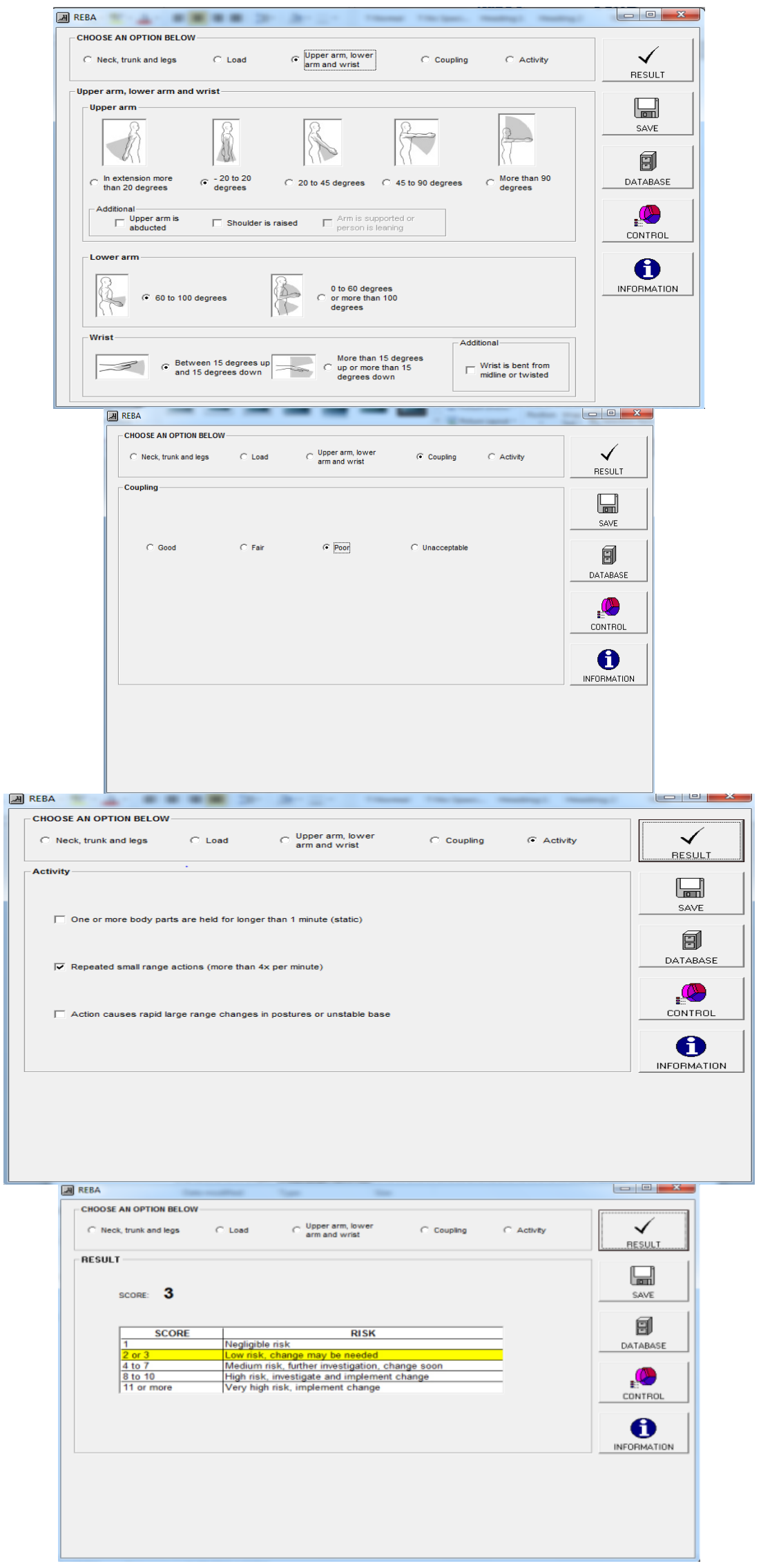

Gambar 8. Pengolahan Data REBA Posisi Mengambil Gulungan Benang dari Rak Benang Tingkat Tengah (Skenario 1b) Lanjutan 
PERBAIKAN POSTUR KERJA (Evita, dkk.)

Berikut merupakan rangkuman hasil pengolahan REBA untuk keenam skenario yang diamatin:

Tabel 2. Rangkuman Hasil Pengolahan Data REBA Aktual untuk TFO Atas

\begin{tabular}{|c|c|c|c|c|c|c|}
\hline Penilaian & Skenario $1 b$ & Skenario 1c & Skenario $2 b$ & Skenario 3b & Skenario $4 c$ & Skenario $4 d$ \\
\hline Neck & $0-20$ derajat & $0-20$ derajat & $0-20$ derajat & $0-20$ derajat & $0-20$ derajat & $0-20$ derajat \\
\hline Trunk & $0-20$ derajat & Lurus & Lurus & Lurus & $0-20$ derajat & Lurus \\
\hline Legs & $\begin{array}{c}\text { Bertumpu pada } \\
\text { dua kaki }\end{array}$ & $\begin{array}{c}\text { Bertumpu pada } \\
\text { dua kaki }\end{array}$ & $\begin{array}{c}\text { Bertumpu pada } \\
\text { dua kaki }\end{array}$ & $\begin{array}{c}\text { Bertumpu pada } \\
\text { dua kaki }\end{array}$ & $\begin{array}{c}\text { Bertumpu pada } \\
\text { dua kaki }\end{array}$ & $\begin{array}{c}\text { Bertumpu pada } \\
\text { dua kaki }\end{array}$ \\
\hline Load & $<5 \mathrm{~kg}$ & $<5 \mathrm{~kg}$ & $<5 \mathrm{~kg}$ & $<5 \mathrm{~kg}$ & $<5 \mathrm{~kg}$ & $<5 \mathrm{~kg}$ \\
\hline Upper Arm & -20-20 derajat & 20-45 derajat & 45-90 derajat & 20-45 derajat & 45-90 derajat & $>90$ derajat \\
\hline Lower Arm & 60-100 derajat & $\begin{array}{c}\text { 0-60 derajat atau } \\
\text { lebih dari } 100 \\
\text { derajat }\end{array}$ & 60-100 derajat & 60-100 derajat & 60-100 derajat & 60-100 derajat \\
\hline Wrist & $\begin{array}{l}\text { Antara } 15 \text { derajat } \\
\text { ke atas dan } 15 \\
\text { derajat ke bawah }\end{array}$ & $\begin{array}{c}>15 \text { derajat atau } \\
\text { lebih dari } 100 \\
\text { derajat }\end{array}$ & $\begin{array}{c}\text { Antara } 15 \\
\text { derajat ke atas } \\
\text { dan } 15 \text { derajat ke } \\
\text { bawah }\end{array}$ & $\begin{array}{c}>15 \text { derajat atau } \\
\text { lebih dari } 100 \\
\text { derajat }\end{array}$ & $\begin{array}{l}\text { Antara } 15 \text { derajat } \\
\text { ke atas dan } 15 \\
\text { derajat ke bawah }\end{array}$ & $\begin{array}{l}\text { Antara } 15 \text { derajat } \\
\text { ke atas dan } 15 \\
\text { derajat ke bawah }\end{array}$ \\
\hline Coupling & Poor & Poor & Poor & Poor & Poor & Poor \\
\hline Activity & Repeated & Repeated & Repeated & Repeated & Repeated & Repeated \\
\hline Hasil Score REBA & 3 & 4 & 4 & 4 & 4 & 4 \\
\hline Resiko & Rendah & Menengah & Menengah & Menengah & Menengah & Menengah \\
\hline Tindakan & $\begin{array}{c}\text { Perbaikan } \\
\text { mungkin perlu } \\
\text { dilakukan }\end{array}$ & $\begin{array}{l}\text { Perbaikan perlu } \\
\text { dilakukan }\end{array}$ & $\begin{array}{l}\text { Perbaikan perlu } \\
\text { dilakukan }\end{array}$ & $\begin{array}{c}\text { Perbaikan perlu } \\
\text { dilakukan }\end{array}$ & $\begin{array}{l}\text { Perbaikan perlu } \\
\text { dilakukan }\end{array}$ & $\begin{array}{l}\text { Perbaikan perlu } \\
\text { dilakukan }\end{array}$ \\
\hline
\end{tabular}

Dapat disimpulkan pada aktivitas pengerjaan pada rak atas dan TFO atas menimbulkan resiko rendah dan menengah seperti yang telah di keluhkan oleh operator melalui kuesioner Nordic Body Map yaitu dengan adanya gejala sakit yang dialami operator pada bagian lengan karena diharuskan untuk menjangkau terlalu tinggi dan dilakukan secara repetitif sehingga sudut tubuh operator menjadi buruk untuk melakukan aktivitas tersebut.

\subsection{Usulan Fasilitas Fisik}

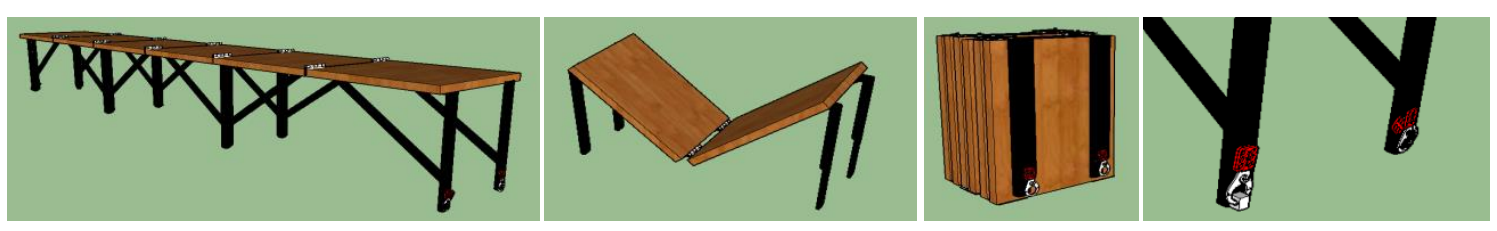

Gambar 9. Usulan Fasilitas Fisik Pijakan Kaki TFO Atas

Tabel 3. Antropometri Usulan Pijakan Kaki

\begin{tabular}{|c|c|c|c|c|c|c|c|c|c|}
\hline \multirow[t]{2}{*}{$\mathrm{N} 0}$. & \multirow[t]{2}{*}{ Bagian Produk } & \multirow[t]{2}{*}{ Dimensi(cm) } & \multirow[t]{2}{*}{ Data Anthropometri } & \multirow{2}{*}{$\begin{array}{l}\text { Jenis } \\
\text { Kelamin }\end{array}$} & \multirow{2}{*}{ Persentil|(\%) } & \multirow[t]{2}{*}{ Besar (cm) } & \multicolumn{2}{|c|}{ Allowance } & \multirow{2}{*}{ Ukuran Yang Diusulkan(cm) } \\
\hline & & & & & & & Jenis I & $\operatorname{Vurran}(\mathrm{cm})$ & \\
\hline \multirow{3}{*}{1} & \multirow{3}{*}{ PijakanKaki } & Panjang & (4 Panjang TF0) & $\cdot$ & . & $(4 \times 25)=100$ & \begin{tabular}{|l|}
$\cdot$ \\
\end{tabular} & $\cdot$ & 100 \\
\hline & & Lebar & Panjang Telapak Kaki & Wanita & 95 & 24.8 & . & . & 24.8 \\
\hline & & TinggiDariTanah & $\begin{array}{c}\text { TingoiTF0 Bawaht } 1 / 2 \text { TingoitF0 Atas- } \\
\text { Tingi Siku Berdiri }\end{array}$ & Wanita & 5 & $\begin{array}{c}80+40-88.6 \\
=31.4\end{array}$ & SolSepatu & $1 \mathrm{~cm}$ & 30.4 \\
\hline
\end{tabular}

Tinggi dari tanah disesuaikan dengan mesin TFO dimana tinggi mesin TFO bawah adalah $80 \mathrm{~cm}$ ditambah dengan setengah tinggi mesin TFO atas dan dikurangin dengan tinggi siku berdiri pada wanita dengan persentil 5\% yaitu $31.4 \mathrm{~cm}$. Hal ini dikarenakan agar penjangkauan ke bagian bawah dan gulungan atas dapat terbagi membentuk sudut ke atas dan ke bawah dalam range yang sama. Selain itu, terdapat allowance untuk sol sepatu yang digunakan yaitu sebesar $1 \mathrm{~cm}$ sehingga tinggi dari tanah menjadi $30.4 \mathrm{~cm}$. Berikut merupakan ilustrasi untuk menentukan tinggi dari pijakan kaki: 


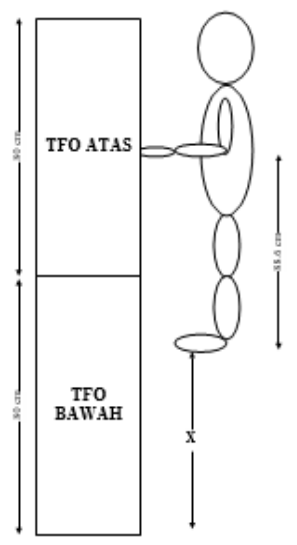

$$
\begin{aligned}
& \mathrm{X}=\text { TFO Bawah }+0.5 \text { TFO Atas }- \text { Tinggi Siku Berdiri } \\
& =80+0.5(80)-88.6=31.4 \mathrm{~cm}
\end{aligned}
$$

Gambar 10. Ilustrasi Penentuan Tinggi Pijakan Kaki

Pijakan kaki yang diusulkan terbuat dari kayu dan besi agar operator dapat lebih nyaman dalam bekerja dan dimensi yang digunakan untuk perancangan juga telah disesuaikan dengan data antropometri tubuh manusia serta disesuaikan pula dengan kondisi mesin tempat operator bekerja. Terdapat pula pengunci di bagian ujung pijakan kaki yang berfungsi agar pijakan kaki tidak jungkir balik ketika digunakan pada salah satu sisi. Mekanisme dari pengunci ini adalah dengan menggeser tuas di bagian atas dan tuas akan terhubung langsung dengan pengait yang berada di bagian bawah sehingga pengait terbuka dan dapat mengunci dengan lubang yang menyatu dengan lantai. Kelebihan dari pijakan kaki ini adalah adalah dapat mengurangi resiko MSDs pada operator untuk aktivitas pengerjaan di TFO atas dan praktis karena dapat dilipat sehingga memudahkan penyimpanan.

\subsection{Analisis Postur Tubuh Operator Setelah Usulan TFO Atas}

Sudut tubuh operator usulan akan dihitung dengan menggunakan aplikasi ergofellow kembali yang nantinya merupakan inputan untuk pengolahan metode REBA. Berikut merupakan identifikasi sudut tubuh operator dengan menggunakan aplikasi 3DSSPP:

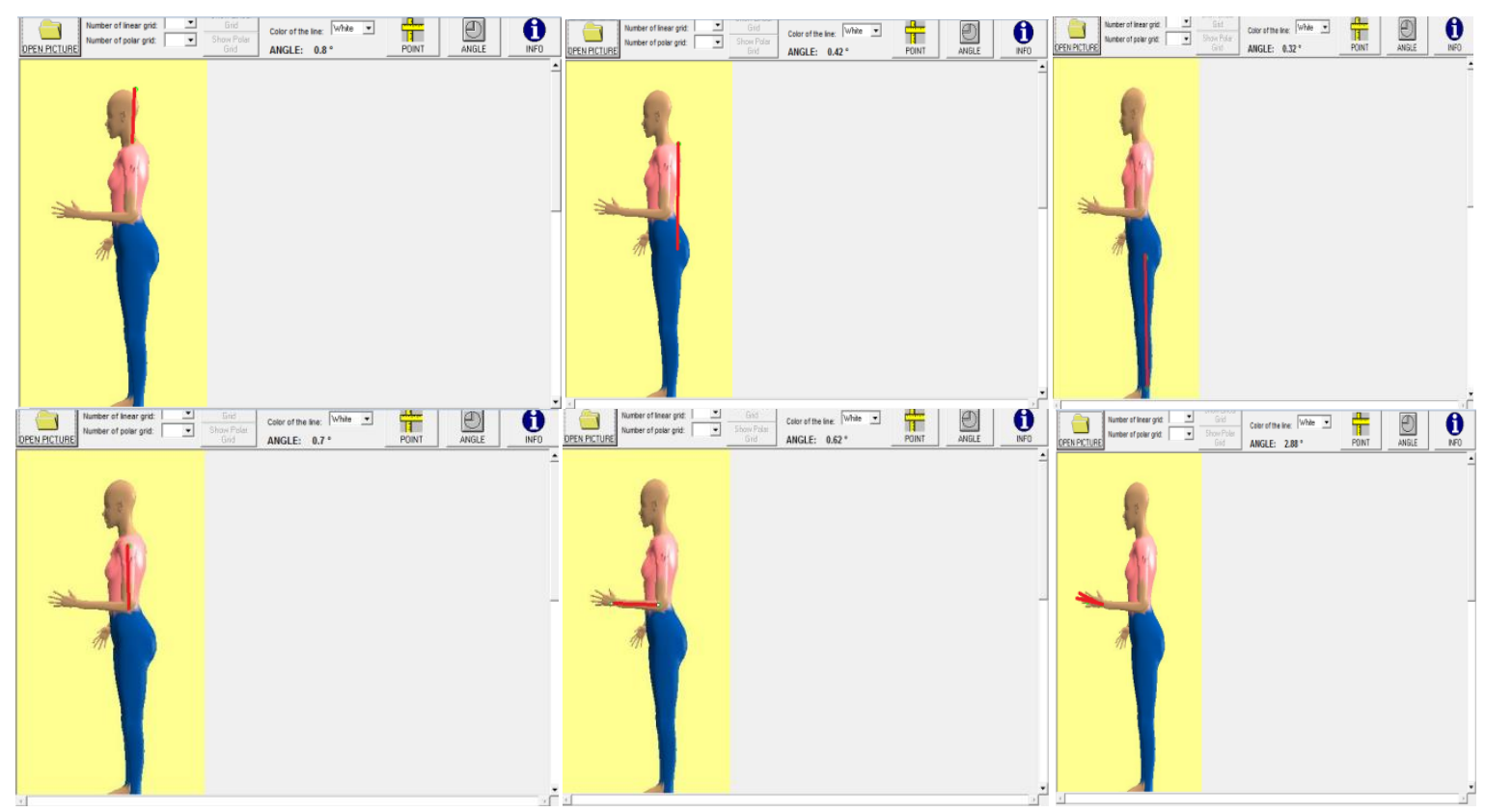

Gambar 11. Sudut Tubuh Operator Setelah Usulan Posisi Mengambil Gulungan Benang dari Rak Benang Tingkat Tengah (Skenario 1b) 


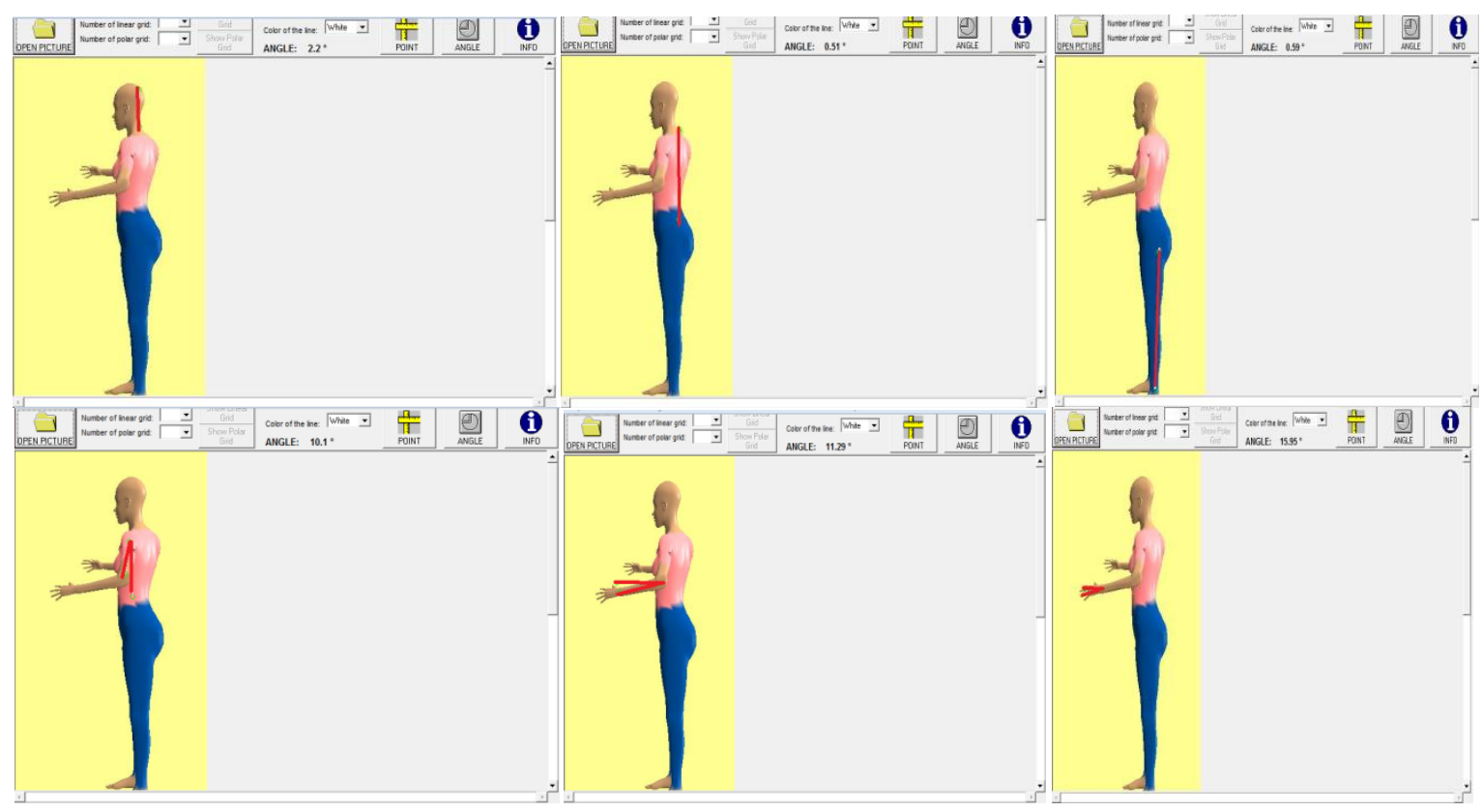

Gambar 12. Sudut Tubuh Operator Setelah UsulanPosisi Mengambil Gulungan Benang dari Rak Benang Tingkat Atas (Skenario 1c)

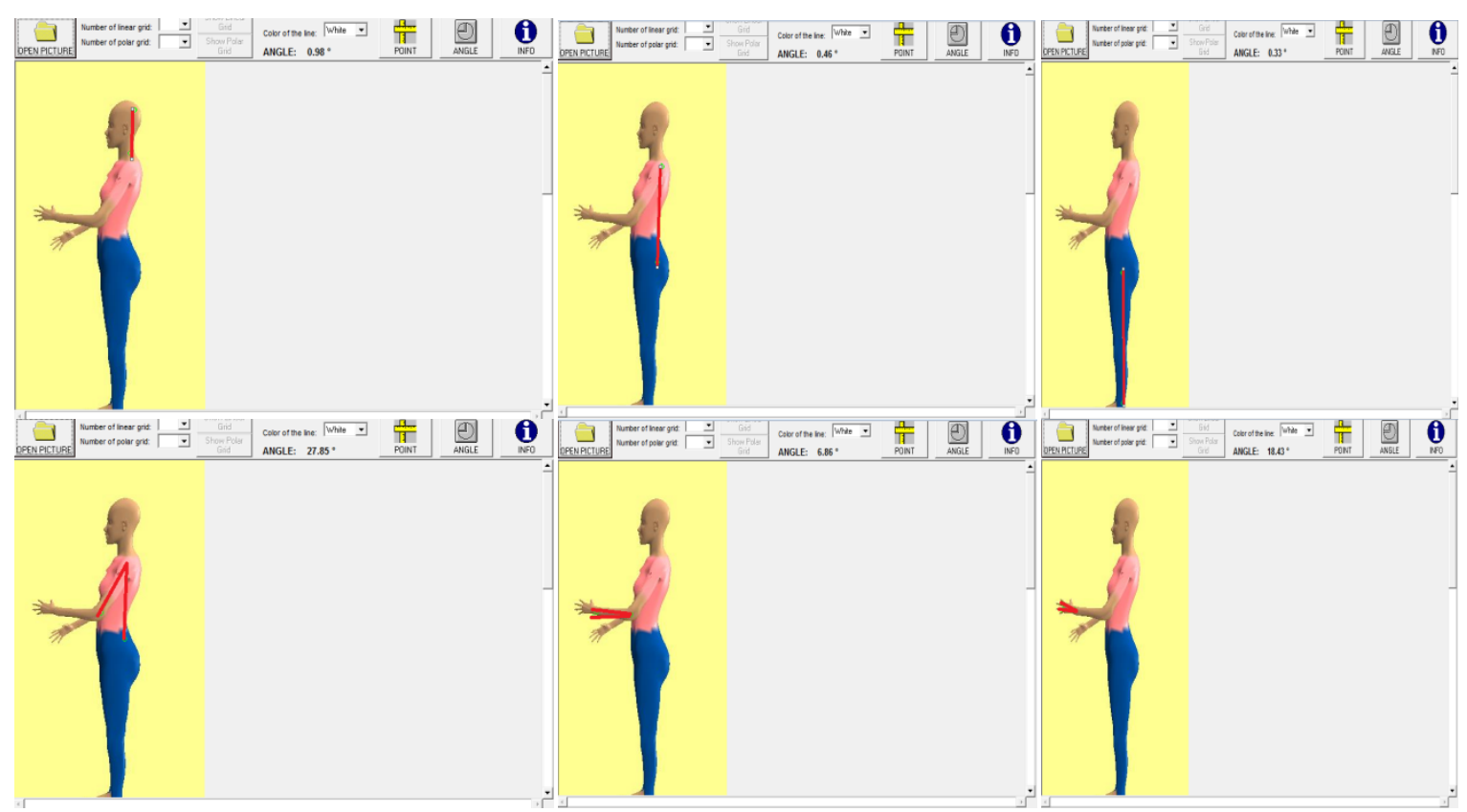

Gambar 13. Sudut Tubuh Operator Setelah Usulan Posisi Mengambil Gulungan Benang dari Mesin Two For One Atas (Skenario 2b) 


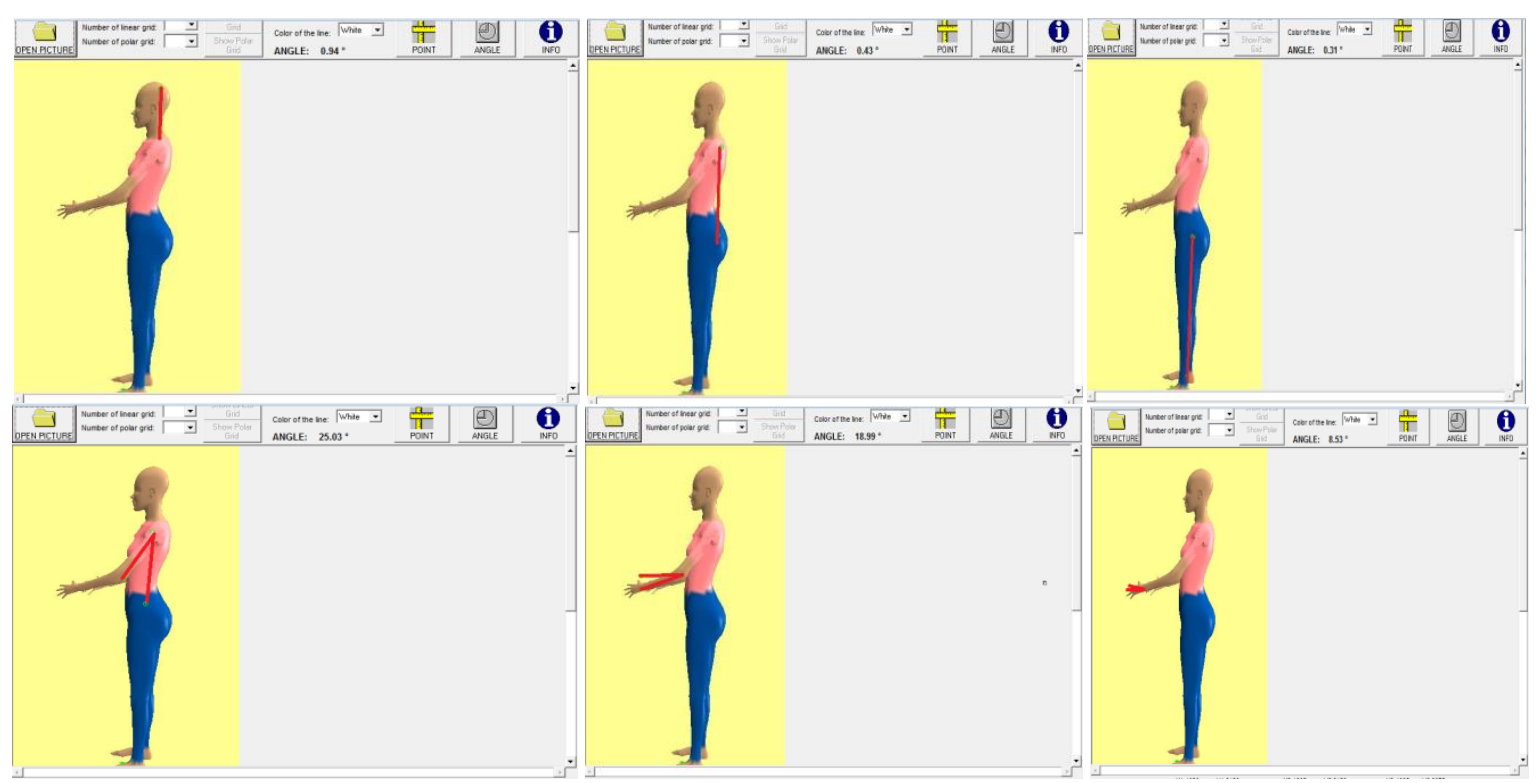

Gambar 14. Sudut Tubuh Operator Setelah Usulan Posisi Meletakkan WIP Ke Mesin Two For One Atas (Skenario 3b)

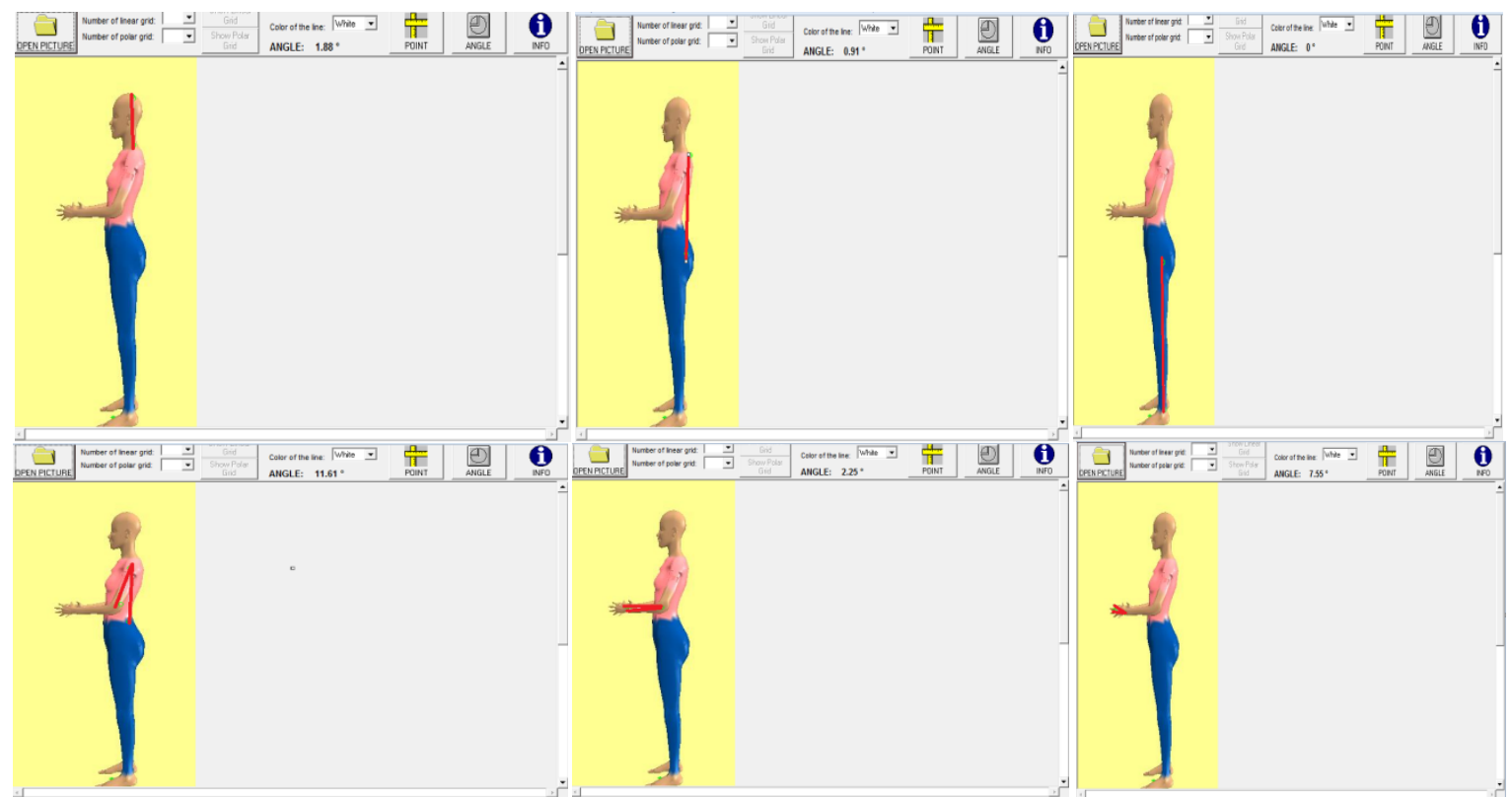

Gambar 15. Sudut Tubuh Operator Setelah Usulan Posisi Melakukan Setup Mengambil Benang Dari Gulungan TFO Atas (Skenario 4c) 


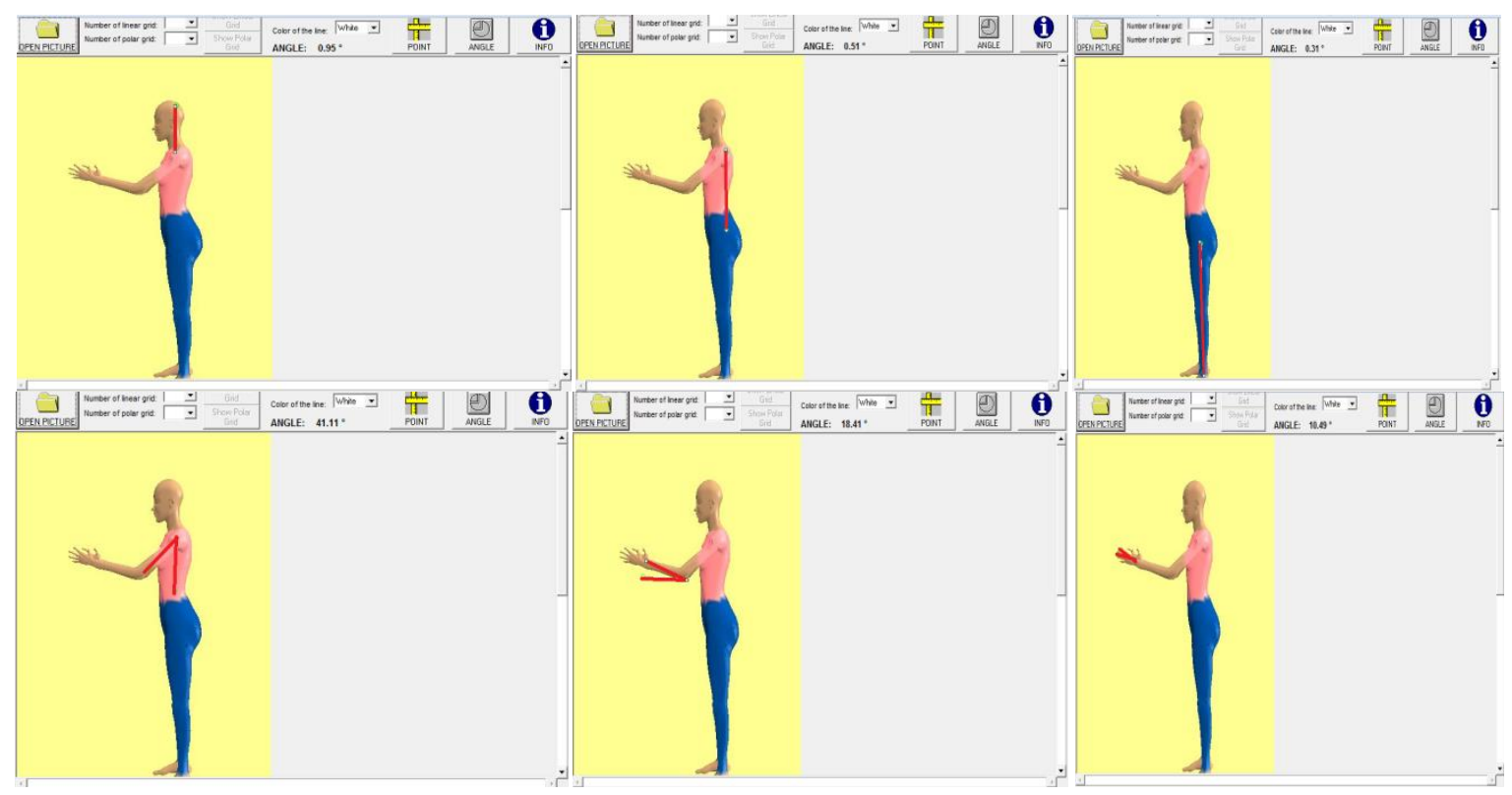

Gambar 16. Sudut Tubuh Operator Setelah UsulanPosisi Melakukan Setup Melilitkan Benang pada Penggulung untuk Di Twist pada TFO bagian Atas (Skenario 4d)

Berikut merupakan rangkuman identifikasi sudut tubuh operator setelah usulan :

Tabel 4. Rangkuman Identifikasi Sudut Tubuh Setelah Usulan untuk TFO Atas

\begin{tabular}{|c|c|c|c|c|c|c|}
\hline Bagian Tubuh & Sudut Skenario 1a & Sudut Skenario 1b & Sudut Skenario 2 & Sudut Skenario 3 & Sudut Skenario 4a & Sudut Skenario 4b \\
\hline Neck & 0.8 & 0.2 & 0.98 & 0.94 & 0.88 & 0.95 \\
\hline Trunk & 0.42 & 0.51 & 0.46 & 0.43 & 0.91 & 0.51 \\
\hline Leg & 0.32 & 0.59 & 0.33 & 0.31 & 0 & 0.31 \\
\hline Upper Arm & 0.7 & 10.1 & 27.85 & 25.03 & 11.61 & 41.11 \\
\hline Lower Arm & 0.62 & 11.29 & 6.86 & 18.99 & 2.25 & 18.41 \\
\hline Wrist & 2.88 & 15.95 & 18.43 & 8.53 & 7.55 & 10.49 \\
\hline
\end{tabular}

\subsection{Analisis Menggunakan REBA Usulan TFO Atas}

Setelah usulan pada pengerjaan di TFO atas dengan menggunakan fasilitas fisik pijakan kaki, kemudian dilakukan perhitungan skor REBA usulan pada operator. Berikut merupakan hasil penilaian neck, trunk, leg, load, upper arm, lower arm, wrist, coupling, dan activity:

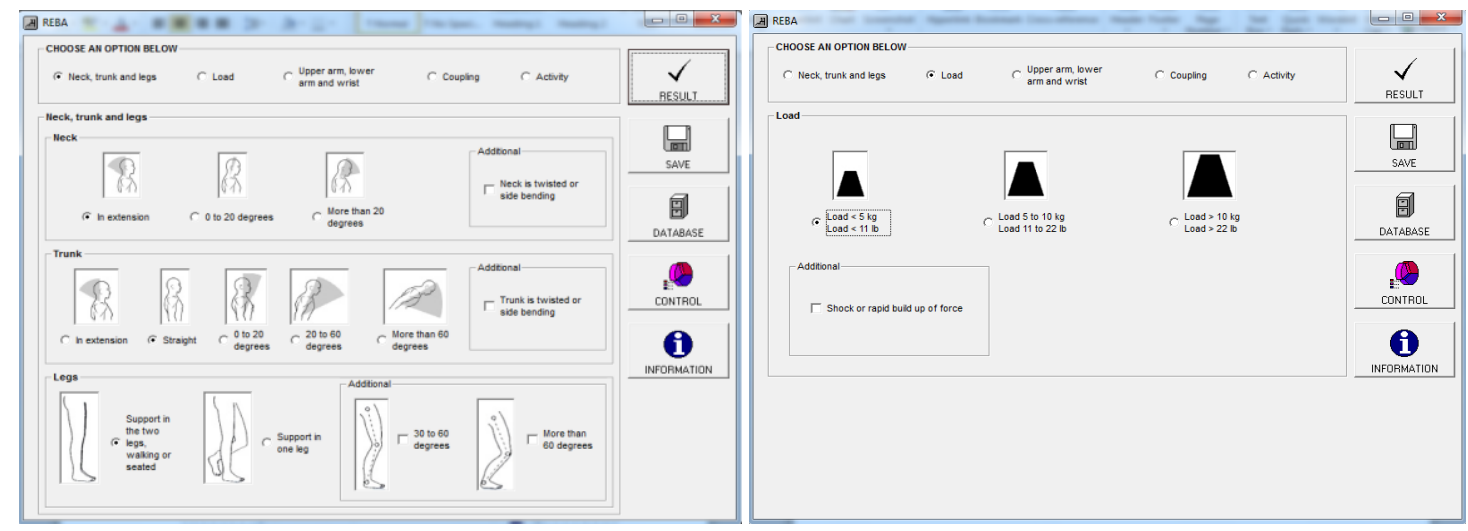

Gambar 17. Pengolahan Data Hasil REBA UsulanPosisi Mengambil Gulungan Benang dari Rak Benang Tingkat Tengah (Skenario 1b) 


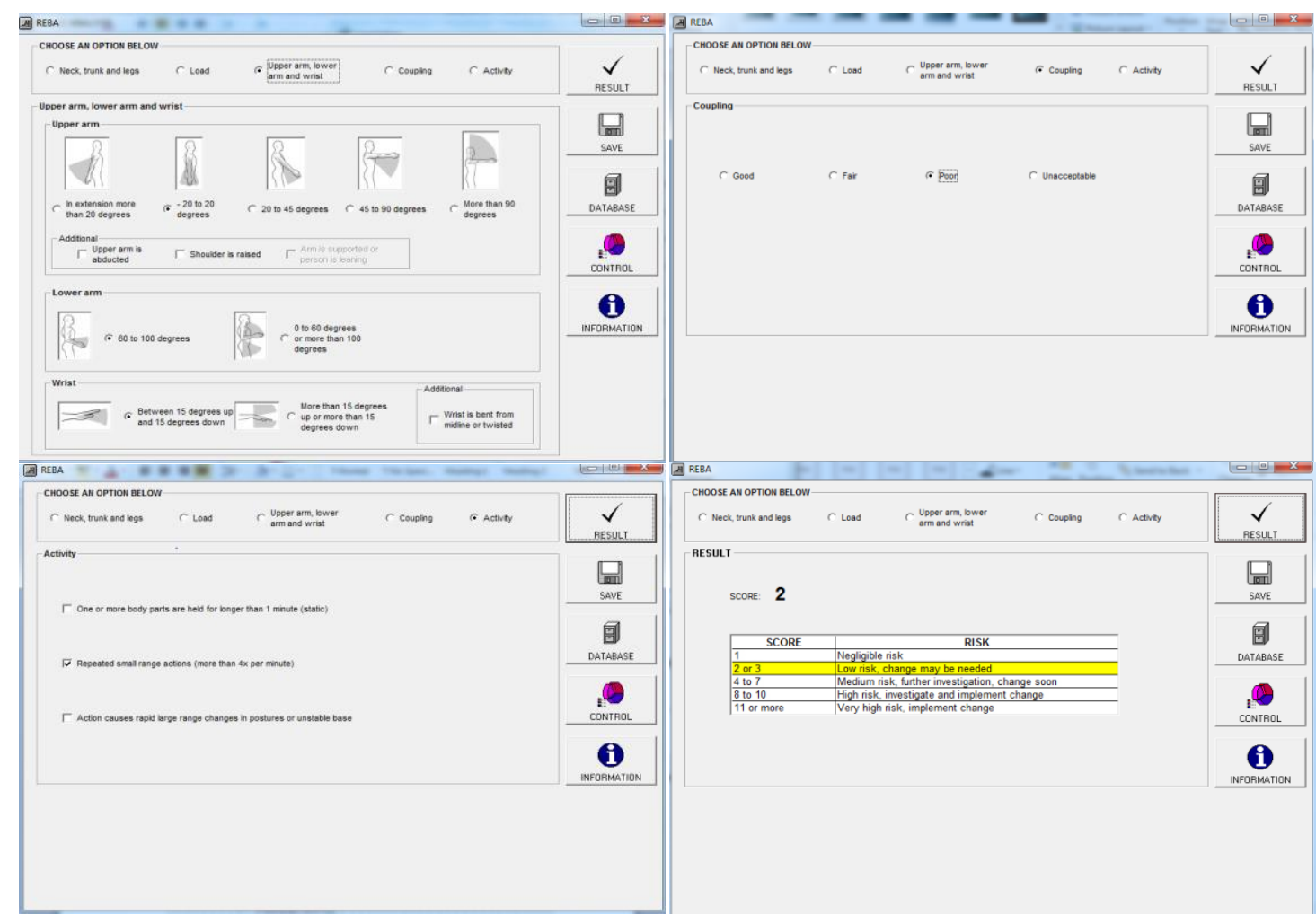

Gambar 17. Pengolahan Data Hasil REBA UsulanPosisi Mengambil Gulungan Benang dari Rak Benang Tingkat Tengah (Skenario 1b) Lanjutan

Berikut merupakan rangkuman hasil pengolahan REBA usulan:

Tabel 5. Rangkuman Hasil Pengolahan Data REBA Usulan Untuk TFO Atas

\begin{tabular}{|c|c|c|c|c|c|c|}
\hline Penilaian & Skenario 1a & Skenario 1b & Skenario 2 & Skenario 3 & Skenario 4a & Skenario 4b \\
\hline Neck & In extension & In extension & In extension & In extension & In extension & In extension \\
\hline Trunk & Lurus & Lurus & Lurus & Lurus & Lurus & Lurus \\
\hline Legs & $\begin{array}{c}\text { Bertumpu pada } \\
\text { dua kaki }\end{array}$ & $\begin{array}{c}\text { Bertumpu pada } \\
\text { dua kaki }\end{array}$ & $\begin{array}{c}\text { Bertumpu pada } \\
\text { dua kaki }\end{array}$ & $\begin{array}{c}\text { Bertumpu pada } \\
\text { dua kaki }\end{array}$ & $\begin{array}{c}\text { Bertumpu pada } \\
\text { dua kaki }\end{array}$ & $\begin{array}{c}\text { Bertumpu pada } \\
\text { dua kaki }\end{array}$ \\
\hline Load & $<5 \mathrm{~kg}$ & $<5 \mathrm{~kg}$ & $<5 \mathrm{~kg}$ & $<5 \mathrm{~kg}$ & $<5 \mathrm{~kg}$ & $<5 \mathrm{~kg}$ \\
\hline Upper Arm & $-20-20$ derajat & $-20-20$ derajat & $20-45$ derajat & $20-45$ derajat & $20-45$ derajat & $20-45$ derajat \\
\hline Lower Arm & 60-100 derajat & $60-100$ derajat & $60-100$ derajat & $60-100$ derajat & $60-100$ derajat & $60-100$ derajat \\
\hline Wrist & $\begin{array}{c}\text { Antara } 15 \text { derajat } \\
\text { ke atas dan 15 } \\
\text { derajat ke bawah }\end{array}$ & $\begin{array}{c}\text { Antara } 15 \text { derajat } \\
\text { ke atas dan 15 } \\
\text { derajat ke bawah }\end{array}$ & $\begin{array}{c}\text { Antara } 15 \\
\text { derajat ke atas } \\
\text { dan } 15 \text { derajat ke } \\
\text { bawah }\end{array}$ & $\begin{array}{c}>15 \text { derajat atau } \\
\text { lebih dari 100 } \\
\text { derajat }\end{array}$ & $\begin{array}{c}\text { Antara } 15 \text { derajat } \\
\text { ke atas dan } 15 \\
\text { derajat ke bawah }\end{array}$ & $\begin{array}{c}\text { Antara } 15 \text { derajat } \\
\text { derajat ke bawah }\end{array}$ \\
\hline Coupling & Poor & Poor & Poor & Poor & Poor & Poor \\
\hline Activity & Repeated & Repeated & Repeated & Repeated & Repeated & Repeated \\
\hline Hasil Score REBA & 2 & 2 & 2 & 2 & 2 & 2 \\
\hline Resiko & Rendah & Rendah & Rendah & Rendah & Rendah & Rendah \\
\hline Tindakan & $\begin{array}{c}\text { Perbaikan } \\
\text { mungkin } \\
\text { diperlukan }\end{array}$ & $\begin{array}{c}\text { Perbaikan } \\
\text { mungkin } \\
\text { diperlukan }\end{array}$ & $\begin{array}{c}\text { Perbaikan } \\
\text { mungkin } \\
\text { diperlukan }\end{array}$ & $\begin{array}{c}\text { Perbaikan } \\
\text { mungkin } \\
\text { diperlukan }\end{array}$ & $\begin{array}{c}\text { Perbaikan } \\
\text { mungkin } \\
\text { diperlukan }\end{array}$ & $\begin{array}{c}\text { Perbaikan } \\
\text { mungkin } \\
\text { diperlukan }\end{array}$ \\
\hline
\end{tabular}

Usulan yang diberikan menunjukkan adanya penurunan resiko cedera yang dialami oleh operator aktivitas pekerjaan pada TFO atas. Resiko yang terjadi pada TFO atas dapat diturunkan menjadi resiko rendah dan usulan belum mampu menurunkan hingga tidak adanya resiko dikarenakan pekerjaan tersebut dilakukan terlalu repetitif. 


\section{Kesimpulan dan Saran}

Berdasarkan analisis metode REBA (Rapid Entire Body Assesment) actual pada posisi mengambil gulungan benang dari rak benang tingkat tengah (Skenario 1b), posisi mengambil gulungan benang dari rak benang tingkat tertinggi (Skenario 1c), posisi mengambil gulungan benang dari mesin Two For One bagian atas(Skenario 2b), posisi.meletakkan WIP ke mesin Two For One bagian atas(Skenario 3b), posisi mengambil benang dari gulungan bagian TFO atas (Skenario 4c), dan posisi melilitkan benang pada penggulung untuk di twist pada TFO bagian atas (Skenario 4d) memiliki score range score 3-4 yaitu tingkat resiko rendah sampai menengah yang artinya perbaikan perlu dilakukan. Untuk mengurangi tingkat resiko cedera pada pekerja, diusulkan fasilitas fisik berupa pijakan kaki yang disesuaikan dengan kondisi TFO atas dan antropometri operator untuk membantu operator pada saat setup di TFO bagian atas. Hasil score dari REBA usulan mengalami penurunan resiko cedera, yang menunjukkan bahwa pemberian fasilitas fisik mampu menurunkan resiko cedera pada operator.

\section{Daftar Pustaka}

Chaffin, Don B. (2006), “Occupational Biomechanic”, New York: John Wiley \& Sons.

Evita, Sarvia E. (2017), "Perbaikan Postur Kerja pada Operator Stasiun Two for One Bawah Menggunakan Metode REBA", Jurnal Sains, Teknologi dan Industri, Vol. 14, No.2, Juni 2017, pp.199- 208.

Hignett, S., \& McAtamney, L. (2000), "Rapid Entire Body Assessment (REBA"), Applied Ergonomics, 31(2), 201-205.

Nurmianto, E. (2004), “Ergonomi : Konsep Dasar dan Aplikasinya”, ITS Surabaya.

Stevenson, M.G. (1989), "Lecture Notes On The Principles of Ergonomics”, University of New South Wales, Sydney.

Susihono, Wahyu (2009), "Rancangan Ulang Mesin Pemotong Singkong Semi Otomatis dengan Memperhatikan Aspek-Aspek Ergonomis Kerja", Proceeding Seminar Nasional Aplikasi Program K3 dan Ergonomi ditempat Kerja, Univ. Sumatra Utara, halaman A12-1 s/d A12-10, Medan. 